\title{
Bacteriological Quality Evaluation of Ready-to-Eat Pineapple Fruit Slices Sold in Markets around Port Harcourt and it's Environ in Rivers State, Nigeria
}

\author{
${ }^{* 1}$ OKORONKWO, FI; ${ }^{2}$ DISEGHA, GC \\ ${ }^{*}$ Department of Microbiology, University of Port Harcourt, Choba, Rivers State, Nigeria \\ ${ }^{2}$ Department of Microbiology, Rivers State University, Port Harcourt, Rivers State, Nigeria \\ *Corresponding Author Email:fihuoma245@yahoo.com
}

\begin{abstract}
Thirty-six samples of "ready to eat" pineapple samples collected in the morning and evening from six different markets in Port Harcourt were analyzed to determine their bacteriological quality. All the pineapple slices examined were contaminated with some bacterial species. The average microbial load of the sample on Nutrient agar, MacConkey agar and Mannitol salt agar for the morning and evening samples were $6.6672 \times 10^{6} \mathrm{cfu} / \mathrm{g}$, $2.5833 \times 10^{4} \mathrm{cfu} / \mathrm{g}$ and $8.0000 \times 10^{3} \mathrm{cfu} / \mathrm{g}$ respectively while those of the evening samples were $1.2494 \times 10^{7} \mathrm{cfu} / \mathrm{g}$, $3.9688 \times 10^{4} \mathrm{cfu} / \mathrm{g}$ and $8.8888 \times 10^{3} \mathrm{cfu} / \mathrm{g}$ respectively. The total heterotrophic bacterial count on the different samples bought at different times (morning and evening) were significantly different at probability $\mathrm{P}<0.05$ while $E$. coli and Staphylococcal counts on the different media at the different times (morning and evening) were not significant at $\mathrm{P}>0.05$. The predominant genera of bacteria observed were Escherichia, Staphylococcus, Klebsiella, Shigella, Enterobacter, Providencia, Proteus, Serratia, Salmonella and Citrobacter with Escherichia having the highest frequency of occurrence (23.61\%). These findings suggest that most "ready to eat" pineapples hawked in the local markets may be implicated in Public Health issues as bacterial agents responsible for food poisoning were isolated from them. The need for improvement and maintenance of good hygiene practices by food handlers and vendors in these markets and trading outlets is recommended.
\end{abstract}

DOI: $\underline{\text { https://dx.doi.org/10.4314/jasem.v24i8.8 }}$

Copyright: Copyright $(\mathcal{C} 2020$ Okoronkwo and Disegha. This is an open access article distributed under the Creative Commons Attribution License (CCL), which permits unrestricted use, distribution, and reproduction in any medium, provided the original work is properly cited.

Dates: Received: 30 May 2020; Revised: 03 July 2020; Accepted: 05August 2020

Keywords: Pineapple, Bacteria, Fruit, Rivers state, Ready-to-eat

Fruits include citrus fruits such as lemon, lime, orange, grapefruit, pears, apples, bananas, pawpaw, pineapples, mangoes, guavas, and many others. (Ihekoronye and Ngoddy, 1985). Pineapple fruit is known for its excellent supply of vitamins, sugar and fibre (Nwachukwu and Ezejiaku, 2014; Lima et al., 2019). It is one of the fruits commonly peeled, cut, sliced, wrapped in transparent polythene bags and sold at cheaper rates in the markets because consumers may not have time to prepare the fruit on their own or they may not have enough money to buy the whole fruit which is always more expensive than the sliced ones (Buckley et al., 2007; Lima et al., 2019). These traders cut the pineapple into different sizes for different prices and sold to the consumers without proper hygienic handling and refrigeration. They stay for several hours depending on the nature of the sale for the day. They remain at temperatures according to the atmospheric condition of that area. This leads to the growth of spoilage and pathogenic organisms like bacteria, yeast or molds when conditions (moisture, warmth and others) become favorable for their propagation. (Isong, 1977). The food consumed has a direct influence on health. It is therefore an important task for food inspectors, food manufacturers and food handlers to keep food safe from pathogenic microorganisms, especially when such foods are to be consumed without further process that is 'ready-toeat' foods or fast foods. (Owhe - Ureghe et al., 1993; Tsang, 2002; Oranusi and Braide, 2012). The exposure and handling of these pineapples in the local markets and other outlets during sales has prompted the need for assessment, therefore, this paper reports the bacteriological quality evaluation of some ready to-eat pineapple fruit slices sold in markets around Port Harcourt and its environ in Rivers State, Nigeria.

\section{MATERIAL AND METHODS}

Peeled, sliced pineapple fruits packaged in transparent polythene bags were bought from Choba, Rumuokuta, Rumuokoro, Mile 3, Mile 1, and Timber markets, all in Port Harcourt, Nigeria. Also, a pineapple sample processed in the laboratory under a standard hygiene conditions was used as a control sample. The samples were collected in the morning and evenings from the same vendors. Samples were collected between 8 to 10 o'clock in the mornings and between 4 to 6 o'clock in the evenings. 
Estimation of the microbial load: Twenty grams (20g) of the pineapple sample was weighed out aseptically and put into $180 \mathrm{ml}$ of sterile diluents $(0.1 \%$ peptone water) and homogenized using a sterile blender (Saisho, Magic Blender, 1831). This gave an evenly dispersed microbial population in the liquid (physiological saline). Tenfold serial dilutions were made by collecting $1 \mathrm{ml}$ of the homogenate and diluting in sterile $9 \mathrm{ml}$ distilled water. Thereafter, an aliquot of $0.1 \mathrm{ml}$ of the desired dilution was inoculated in replicate on already prepared Nutrient agar, MacConkey agar, Mannitol salt agar plates using the spread plate method and incubated aerobically at $37^{\circ} \mathrm{C}$ for $24-48$ hours. Distinct colonies were counted after incubation and results expressed as colony-forming units per gram $(\mathrm{Cfu} / \mathrm{g})$. The bacterial isolates from the samples were identified based on their Gram reactions, colonial morphology and some biochemical tests according to Sneath et al., (1986).

\section{RESULTS AND DISCUSSION}

The mean total bacterial count on nutrient agar of the morning samples and the evening sample varied from $6.6672 \times 10^{6} \mathrm{cfu} / \mathrm{g}$ and $1.2494 \times 10^{7} \mathrm{cfu} / \mathrm{g}$. The mean total bacterial count on MacConkey agar between the morning and the evening samples varied from $2.5833 \times 10^{4} \mathrm{cfu} / \mathrm{g}$ and $3.9688 \times 10^{4} \mathrm{cfu} / \mathrm{g}$. The mean bacterial count on Mannitol Salt agar between the morning and evening samples varied from $8.0000 \times 10^{3} \mathrm{cfu} / \mathrm{g}$ and $8.8888 \times 10^{3} \mathrm{cfu} / \mathrm{g}$ respectively. The microbial load of the control sample on Nutrient agar was $1.75 \times 10^{5}$ and on MacConkey agar it was 5.0 $\times 10^{3}$. There was no growth on Mannitol salt agar. The student's t-test result obtained showed that the total heterotrophic bacterial count on the different samples collected at different times (morning and evening) was significantly different at probability $(\mathrm{P}<0.05)$ but there was no significant difference between the $E$. coli and Staphylococcal counts on the different media at the different times (morning and evening) at $(\mathrm{P}>0.05)$. A total of 42 bacteria genera were isolated from the test samples with $E$. coli having the highest frequency of occurrence $(23.61 \%)$ followed by Staphylococcus aureus $(16.67 \%)$. The microbial load of the control sample is as shown in Table 1. It was observed that the total heterotrophic count on Nutrient agar and MacConkey agar showed much-reduced number when compared to the commercially processed pineapples. Staphylococcus aureus was not detected on the Mannitol Salt agar in the control.

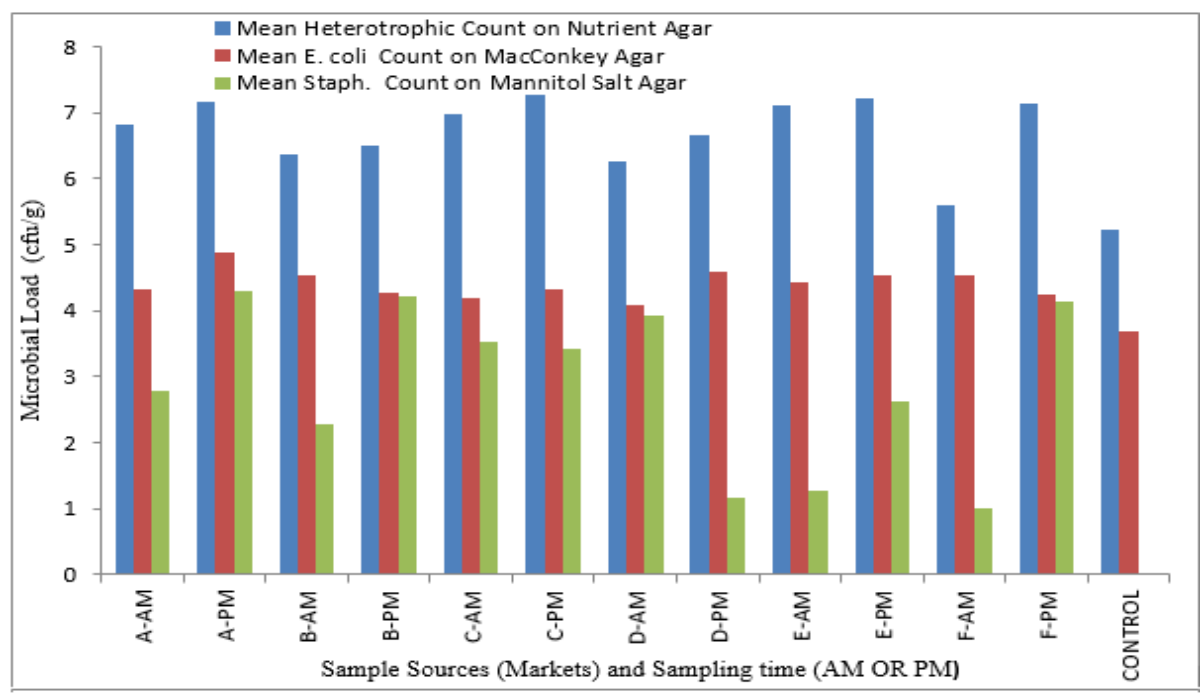

Fig 1. Total microbial load of microorganisms on Nutrient agar, MacConkey agar and Mannitol salt agar from samples collected in the mornings and evenings from different markets in Port Harcourt.

Key: A-Choba market; B-Rumuokoro market; C-Rumuokuta market; D-Mile 3 market; E-Mile 1 market; F-Timber market

Table 1. The recommended limits of bacterial contaminants on ready-to-eat foods

\begin{tabular}{lllll}
\hline & Satisfactory & Acceptable & Unsatisfactory & Unacceptable Potentially Hazardous \\
\hline Aerobic Colony Count & $<10^{6}$ & $10^{6}-<10^{7}$ & $\geq 10^{7}$ & Not acceptable (N/A) \\
E. coli (total) & $<20$ & $20-<100$ & $\geq 100$ & N/A \\
Staphylococcusaureus & $<20$ & $20-<100$ & $100<10^{4}$ & $\geq 10^{4}$ \\
\hline \multicolumn{4}{c}{ (Microbiological Guidelines for Food, } & 2014).Microbiological quality in cfu/g
\end{tabular}

(Microbiological Guidelines for Food, 2014).Microbiological quality in cfu/g

The present study revealed that all the ready-to-eat pineapple samples had marked differences especially between the morning and evening samples with the evening samples always having higher heterotrophic counts than the morning samples. The determination of the total heterotrophic count was carried out to give 
a valuable indication of the overall hygiene quality of the pineapple samples in terms of the numbers of psychrophilic and mesophilic organisms present in the sample. It could also be seen that compared to the recommended standard, the aerobic bacterial count of the morning samples is satisfactory while most of the evening samples are both acceptable and unsatisfactory. The result of the laboratory processed pineapple sample (control) was satisfactory. The $E$. coli counts on MacConkey agar were unsatisfactory as both morning and evening samples exceeded $10^{2} \mathrm{cfu} / \mathrm{g}$. The staphylococcal count on Mannitol salt agar showed unsatisfactory results and the control has no Staphylococcus aureus in it which is a satisfactory result. These results reveal that these pineapples are microbiologically unacceptable for consumption when compared to the control prepared in an aseptic condition. The high bacterial counts of the evening samples could be due to the relatively high moisture content of these pineapples which could be attributed to time factor because the long period of storage in the thin transparent polythene bags and the effects of external parameters like warmth and moisture will favour a greater increase in the metabolism of the bacteria and hence support the increase of the bacterial population. Also, the catabolic breakdown of the sugars in the pineapple in the transparent polythene bags which are seen from its colour changes, decrease in the $\mathrm{pH}$ value of the pineapple samples which makes it ideal for bacterial growths and fermentation and the oxidation of alcohols produced by some of the microorganisms could also add to the increased number of the microorganisms. Nutrients also leached from the cut fruits can also lead to the microbial load increase. (Viswanathan and Kaur, 2001).

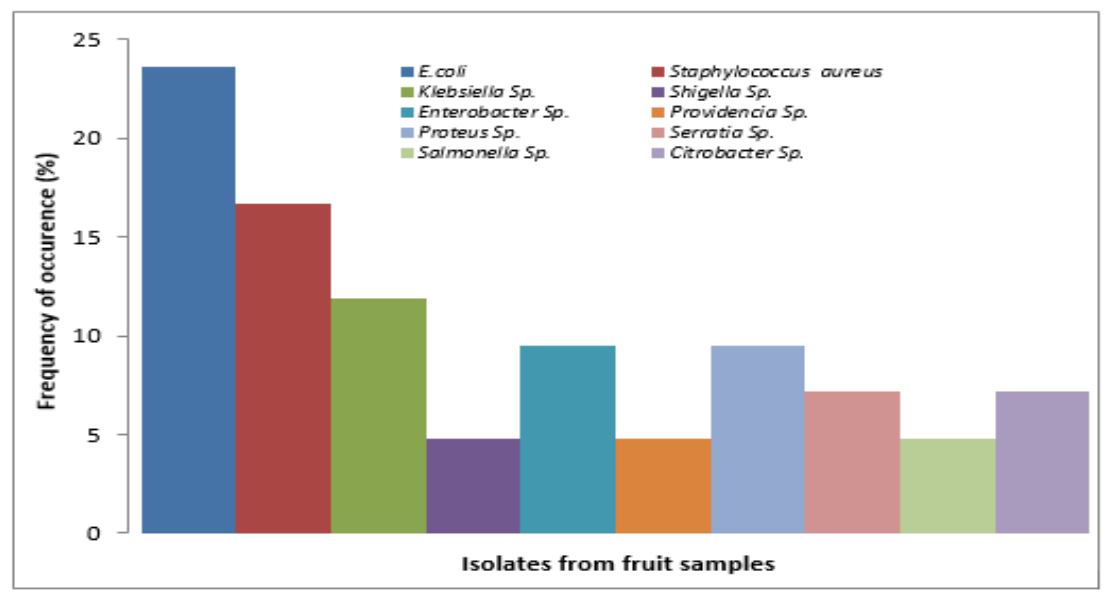

Fig 2. Frequency of Occurrence (\%) of the Bacteria Species Isolated from the Pineapple Samples

Most of the organisms isolated in this study might have been introduced into these pineapple samples from the use of water from a poorly maintained storage tank or water from untreated boreholes for washing and sometimes the fruits also may not be washed before it is cut or the same water is used in washing the fruits many times (Edusie et al., 2016; Asante et $a l ., 2019)$. Poor quality pineapple may also be cut and unhygienic conditions of handling such as packing in partially damaged polythene bags, not washing the hands thoroughly with warm water and soap before preparing the pineapples, not cutting the fruits on a clean washed trays or cutting boards with clean knives and contaminations from the air (dust). All these add to the increase in the bacterial number of the samples. The poor quality of the pineapples could also be from contamination of the fruit at any point throughout the production system. Potential pre-harvest sources include soil, feaces, irrigation water, water used to apply fungicides and insecticides, dusts, insects, inadequately composted manure, wild and domestic animals and human handling. Post-harvest sources of contamination also could be the use of dirty harvesting equipment, dirty transport containers, wild and domestic animals, insects, dust, dirty rinsing water, dirty processing equipment. (Buck et al., 2003). If high standards of hygiene are not observed, faecal coliforms could contaminate the food (pineapple) along perhaps, with Staphylococcus aureus. The use of tap water from a poorly-maintained storage tank or water from a bore-hole to wash the pineapple may pose an additional - risk. Thus both Aeromonas hydrophila and Cryptosporidium parvum have been detected in municipal water supplies, while Lysteria monocytogenes and Yersinia enterocolitica have been isolated from drinking water from wells. Equally relevant could be the finding of Wang and Doyle that E. coli 0157 could survive in a viable state in water for 
12 weeks at $25^{\circ} \mathrm{C}$ although in a non-culturable state (AL - Jedah and Robinson, 2002). Previous studies showed the recovery of enteric bacteria, E. coli and Staphylococcus from ready-to-eat pineapple, pawpaw and watermelon. Chukwu et al., (2010), Daniel et al., (2014), Izah et al., (2015) and Asante et al., (2019) also identified E. coli, S. aureus and Proteus as the bacterial diversity present on pre-cut sliced fresh fruits sold in Kano, Bida and Yenegoa. The results from this study agree with these facts and these pineapple samples could be a source of diarrhea and or gastrointestinal disturbances to both adult and children as they exceed the microbiological limits and also showed that they are prepared in an unhealthy condition as compared to the control which has a very reduced count since it was prepared under an aseptic condition (Chukwu et al., 2010; Allafi and Busamri, 2011; Izah et al., 2015).The presence of Escherichia coli and Staphylococcus aureus in large quantities in the pineapple samples indicates contamination from human sources. This could lead to gastrointestinal disturbances. Generally, Staphylococcus existed in low numbers in the pineapple samples in agreement with Fraizer and Westhoff (1978) who said that Staphylococcus may be expected to exist, at least, in low numbers in any of the food products that are of animal origin or those that are handled directly by humans unless heat processing steps are applied to affect their destruction. This is because other food bacteria competing with the Staphylococcus may repress its growth enough to delay or prevent the production of toxins, or the spoilage bacteria may make the food inedible before it is dangerous. The effectiveness of the repression varies with the kinds and numbers of competing organisms Majority of the isolates from the pineapple samples belong to the enterobacteriaceae family. Some of them are potentially pathogenic while others are normal flora of the intestinal tract. An example is the E. coli and Enterobacter while the Shigella and Salmonella, are pathogenic. Infection from the consumption of fruits containing all these organisms is based on the consumer's resistance, the number of the organisms that could make the effective dose of infection and the ineffectiveness of the particular strain. Food poisoning from Staphylococcus aureus takes only a very short period of incubation between $1-8$ hours and about 24 - 72 hours for $E$. coli respectively and symptoms include vomiting, nausea, and diarrhea. (Frazier and Westhoff, 1978). Apart from the isolated organisms, there could be the presence of anaerobic organisms but due to the condition of isolation (aerobic), they were not found in the pineapple samples. An example of such organism is the Clostridium perferingens which causes food infection.
Conclusion: The need for improvement in the hygienic condition of locally marketed fruits (pineapple) cannot be over-emphasized, mainly when such organisms as Staphylococcus aureus, Escherichia coli, Salmonella $\mathrm{Sp}_{2}$ and other bacteria occur in high numbers which are known to be associated with food poisoning or infection. This may go a long way to reduce the numbers of the bacterial population by preventing or reducing the external parameters that result from long storage time and the unhygienic conditions which aid in the metabolism of bacteria which are ubiquitous.

\section{REFERENCES}

Al-Jedah, JH; Robinson, RK (2002). Nutritional Value and Microbiological Safety of Fresh Fruits Juices Sold through Retail Outlets in Quatar. Pakistan J. of Nut. 1(2): 79-81

Allafi, A; Busamri, S (2011).Microbiology of Fresh Oranges after Storage at Room and Refrigeration Temperature Conditions. Int. J. Food Safety, Nut, Pub.Health and Tech.3 (1):1-3

Asante, RO; Odoom, W; Adomako, C; Edusei, VO (2019). Assessment of Microbial Load on FreshCut Pineapple in Koforidua (Ghana) Market. $A d v$. in Nut. Food Sci. 4(2): 1-3

Buck, JW; Walcott RR; Beuchat, LR (2003). Recent Trends in Microbiological Safety of Fruits and Vegetables. Plant Health Progress. Doi: 10.1094/PHP-2003.0121-01-RV

Buckley, M; Cowan, C; McCarthy M (2007). The Convenience Food Market in Great Britain: Convenience Food Lifestyle (CFL) Segments. Appetite, 49(3): 600-617

Chukwu, COC; Chukwu, ID; Onyimba, IA; Umoh, EG; Olarubofin, F; .Olabode, AO (2010). Microbial Quality of Pre-Cut Fruits on Sale in Retail Outlets in Nigeria. Afri. J. Agric. Res. 5(17): 2272-2275

Daniel, AA; Danfulani, S; Barnabas, BB; Peter, G; Ajewole, AE (2014). Microbiological Quality of Sliced Fresh Fruits Sold in Bida, Nigeria. Global J. of Bio. Agric. and Health Sci. 3(3): 178-180

Edusei, VO; Odoom, W; Kwofie, S (2016). Assessment of Freshcut Fruit Handling and Vending in the Central Business Area of Koforidua, Ghana. Asian J. of Agric. and Food Sci.4 (2):102-108 
Frazir, WC; Westhoff, DC (1978). Food Microbiology. $\quad 3^{\text {rd }}$ ed. Tata McGraw-Hill Publishing Company Ltd. New Delhi Pp. 419-457

Ihekoronye, AI; Ngoddy, PO (1985). Integrated Science and Technology for the Tropics. Macmillan Education Ltd, London and Oxford. P. 296.

Isong, NC (1977). Fruits, Vegetables and their Products: Processing and Preservation of Nigerian Fruits and Green Vegetables. Proceedings of their Launching and First Annual Conference, Nig. Inst. of Food Sci. and Tech., 1:5-7, Pp. 49-55

Izah, SC; Asseibai ER; Orutugu, LA (2015). Microbial Quality of Polythene Packaged Sliced Fruits Sold in Major Markets of Yenegoa Metropolis, Nigeria. Point. J. of Bot. and Microbiol. Res. 1 (3): 030-036.

Lima, P C C; Sarzi de Souza, B; Fyfe, S (2019). Influence of the Storage Temperature and Different Packaging on the Physicochemical Quality of Fresh-Cut 'Perola' Pineapple. Articulos de Investigacion/Research Papers, 37(2): 13-19.

Microbiological Guidelines for Food (2014). For Ready-to-eat food in General and Specific Items, Centre for Food Safety. Food and Environmental
Hygiene Department, Queensway, Hong Kong. Pp 17-19.

Nwachukwu, E; Ezejiaku, FC (2014). Microbial and Physicochemical Characteristics of locally Produced Pineapple Juice Treated with Garlic and Ginger. International Journal Curr. Microbiol. Appl. Sci. 3(6): 895-901.

Oranusi, S; Braide, W (2012). A Study of Microbial Safety of Ready -to- Eat Foods Vended on Highways: Onitsha-Owerri, South East Nigeria. Int. Res. J. Microbiol. 3(2): 066-071

Owhe-Ureghe, UB; Ekundayo, OA; Agbonlahor, DE; Oboh, PA; Orhue, P (1993). Bacteriological Examination of some 'Ready -to-eat' Foods Marked in Ekpoma, Edo State of Nigeria. Nig. Food J. 11: 45- 52.

Sneath, PH; Mair, NS; Sharp, ME; Holt, JG (1986). Bergy's Manual of Systematic Bacteriology, Vol 11. Baltima: William Wilkins.

Tsang, D (2002). Microbiological Guidelines for Ready to eat food. Road and Environmental Hygiene Department, Hongkong. Pp 115-116.

Viswanathan, P; Randhir, K (2001). Prevalence and Growth of Pathogens on Salad, Vegetables, Fruits and Sprouts. Int. J. of Hyg. Environ. Health. 20(3): 205-213. 